\title{
Author Correction: Growth hormone regulates neuroendocrine responses to weight loss via AgRP neurons
}

Isadora C. Furigo (10 1, Pryscila D.S. Teixeira1', Gabriel O. de Souza', Gisele C.L. Couto', Guadalupe García Romero ${ }^{1,2}$, Mario Perelló ${ }^{2}$, Renata Frazão ${ }^{3}$, Lucila L. Elias ${ }^{4}$, Martin Metzger ${ }^{1}$, Edward O. List ${ }^{5}$, John J. Kopchick ${ }^{5} \&$ J. Donato Jr (iD ${ }^{1}$

Correction to: Nature Communications; https://doi.org/10.1038/s41467-019-08607-1; published online 08 February 2019

The original version of this Article contained an error in the spelling of the author J. Donato Jr, which was incorrectly given as Donato J. Jr. This has now been corrected in both the PDF and HTML versions of the Article.

Published online: 25 February 2019

cc Open Access This article is licensed under a Creative Commons Attribution 4.0 International License, which permits use, sharing, adaptation, distribution and reproduction in any medium or format, as long as you give appropriate credit to the original author(s) and the source, provide a link to the Creative Commons license, and indicate if changes were made. The images or other third party material in this article are included in the article's Creative Commons license, unless indicated otherwise in a credit line to the material. If material is not included in the article's Creative Commons license and your intended use is not permitted by statutory regulation or exceeds the permitted use, you will need to obtain permission directly from the copyright holder. To view a copy of this license, visit http://creativecommons.org/licenses/by/4.0/.

(C) The Author(s) 2019

\footnotetext{
${ }^{1}$ Department of Physiology and Biophysics, Institute of Biomedical Sciences, University of São Paulo, Av. Prof. Lineu Prestes, 1524, São Paulo, SP 05508-000, Brazil. ${ }^{2}$ Laboratory of Neurophysiology, Multidisciplinary Institute of Cell Biology, Calle 526 y Camino General Belgrano, La Plata, BA 1900, Argentina.

${ }^{3}$ Department of Anatomy, Institute of Biomedical Sciences, University of São Paulo, Av. Prof. Lineu Prestes, 2415, São Paulo, SP 05508-900, Brazil.

${ }^{4}$ Department of Physiology, School of Medicine of Ribeirão Preto, University of São Paulo, Av. Bandeirantes, 3900, Ribeirão Preto, SP 14049-900, Brazil.

${ }^{5}$ Edison Biotechnology Institute and Heritage College of Osteopathic Medicine, Ohio University, Konneker Research Center 206A, Athens, OH 45701, USA.

Correspondence and requests for materials should be addressed to J.D.Jr. (email: jdonato@icb.usp.br)
} 